\title{
HUBUNGAN KONSUMSI TABLET FE DAN LAMA KONSUMSI TABLET FE TERHADAP ANEMIA DALAM KEHAMILAN DI WILAYAH KERJA PUSKESMAS CISAYONG KABUPATEN TASIKMALAYA TAHUN 2018
}

\author{
Santi Susanti0, S.SiT, M.Kes \\ (santiazhari@gmail.com) \\ Marpungah Tunisa
}

\section{Sekolah Tinggi Ilmu Kesehatan STIKes Respati Tasikmalaya}

\section{A. ABSTRAK}

Angka kematian maternal dan perinatal merupakan indikator keberhasilan pelayanan kesehatan, khususnya pelayanan kebidanan dan perinatal. Sampai saat ini angka kematian maternal dan perinatal di Indonesia masih cukup tinggi. Perdarahan sebagai penyebab tertinggi merupakan dampak dari komplikasi atau penyakit saat kehamilan dan persalinan seperti anemia. Prevalensi anemia pada ibu hamil berdasarkan laporan Dinas Kesehatan Kabupaten Tasikmalaya tahun 2016 berkisar 3.137 orang $(6,3 \%)$ dari 49.853 orang. Data Puskesmas Cisayong kasus anemia pada kehamilan tahun 2015 sebanyak 207 orang (20,82\%) dari 994 ibu hamil, sedangkan pada tahun 2016 mengalami peningkatan dimana jumlah ibu hamil anemia sebanyak 244 orang $(21.65 \%)$ dari 1127 ibu hamil. Penelitian ini bertujuan untuk mencari hubungan antara faktor konsumsi tablet Fe dan faktor lama mengkonsumsi tablet $\mathrm{Fe}$ terhadap kejadian anemia dalam kehamilan.

Metode penelitian yang digunakan adalah metode kuantitaif dengan pendekatan cross sectional. Populasi dalam penelitian ini adalah seluruh ibu hamil di wilayah puskesmas Cisayong periode Januari sampai dengan April 2018 berjumlah 454 orang. Tekhnik pengambilan sampel menggunakan proportional random sampling. Tekhnik pengambilan data adalah menggunakan data sekunder. Instrumen yang digunakan adalah format ceklist untuk mengetahui anemia pada ibu hamil, konsumsi tablet fe, dan lama mengkonsumsi tablet Fe. Analisis data menggunakan analisis bivariate dengan menggunakan Uji kai kuadrat

Hasil penelitian menunjukkan hubungan antara konsumsi tablet $\mathrm{Fe}$ dengan anemia dalam kehamilan menunjukkan nilai $\mathrm{p}=0,00$ sehingga disimpulkan bahwa hubungan antara konsumsi tablet Fe dengan anemia dalam kehamilan signifikan. Hubungan antara lama mengkonsumsi tablet Fe dengan anemia dalam kehamilan menunjukkan nilai $p=0,62$. Jika menggunakan tingkat signifikansi $\alpha=0,05$ maka nilai $\mathrm{p}(0,62)>\alpha(0,05)$, sehingga disimpulkan bahwa tidak terdapat hubungan antara lama mengkonsumsi tablet Fe dengan anemia dalam kehamilan.

Simpulan dalam penelitian ini adalah terdapat hubungan antara konsumsi tablet Fe dengan anemia dalam kehamilan dan tidak ada hubungan antara lama mengkonsumsi tablet Fe dengan anemia dalam kehamilan. Saran untuk ibu hamil dianjurkan untuk mengkonsumsi tablet $\mathrm{Fe}$ selama kehamilan secara rutin dan teratur. Ibu hamil juga disarankan untuk mengkonsumsi multivitamin sehingga dapat meningatkan penyerapan Fe dalam mencegah anemia dalam kehmailan.

Kata kunci : Anemia Dalam Kehamilan, Tablet Fe, Lama Konsumsi Fe 


\section{B. LATAR BELAKANG}

Angka kematian maternal dan perinatal merupakan indikator keberhasilan pelayanan kesehatan, khususnya pelayanan kebidanan dan perinatal. Sampai saat ini angka kematian maternal dan perinatal di Indonesia masih cukup tinggi. Menurut hasil Survey Demografi Kesehatan Indonesia (SDKI) tahun 2012 angka kematian ibu mencapai 359/100.000 kelahiran hidup, sedangkan hasil survey tahun 2007 mencapai 228/100.000 kelahiran hidup. Hal ini tampak terjadi peningkatan dari hasil survey sebelumnya. Penyebab utama kematian ibu yaitu perdarahan $(25 \%)$, infeksi (15\%), hipertensi dalam kehamilan (12\%), partus macet (8\%) dan aborsi (13\%) (Saifuddin, 2010).

Perdarahan sebagai penyebab tertinggi merupakan dampak dari komplikasi atau penyakit saat kehamilan dan persalinan seperti anemia. Setiap ibu hamil dengan anemia memiliki risiko untuk terjadi perdarahan postpartum. Hal ini terjadi karena ketidakmampuan uterus untuk berkontraksi yang adekuat. Pada anemia jumlah sel darah merah yang aktif berkurang, sehingga menurunkan jumlah kadar haemoglobin dalam darah (Manuaba, 2012).

Anemia yang sering dijumpai dalam kehamilan adalah anemia karena kekurangan zat besi (Fe ) sehingga lebih dikenal dengan istilah anemia gizi besi (AGB) (Sulityoningsih, 2011). Menurut Manuaba (2008) ibu hamil yang mengalami anemia berdampak buruk terhadap kehamilan, persalinan dan nifas. Dampak pada kehamilan diantaranya adalah abortus, kelahiran prematur, infeksi, hiperemesis gravidarum, perdarahan antepartum dan ketuban pecah dini. Pada persalinan akan berdampak pada gangguan kontraksi berkurang, persalinan berlangsung lama dan dampak pada pasca terjadinya sub involusi uterus, ASI berkurang serta infeksi puerperium.

Prevalensi anemia pada ibu hamil berdasarkan laporan Dinas Kesehatan Kabupaten Tasikmalaya tahun 2016 berkisar 3.137 orang $(6,3 \%)$ dari 49.853 orang (Dinkes Tasikmalaya, 2017). Data Puskesmas Cisayong kasus anemia pada kehamilan tahun 2015 sebanyak 207 orang $(20,82 \%)$ dari 994 ibu hamil, sedangkan pada tahun 2016 mengalami peningkatan dimana jumlah ibu hamil anemia sebanyak 244 orang $(21.65 \%)$ dari $1127 \mathrm{ibu}$ hamil. Cakupan pemberian tablet $\mathrm{Fe}$ pada ibu hamil di wilayah kerja puskesmas Cisayong pada tahun 2016 mencapai 1025 oang (91\%) dari 1127 ibu hamil. Kemudian pada tahun 2017 cakupan pemberian tablet $\mathrm{Fe}$ mencapai 1180 orang $(107,1 \%)$ dari $1102 \mathrm{ibu}$ hamil. Hal ini menunjukkan cakupan Fe lebih dari target yang ditetapkan. Namun ibu hamil anemia mengalami peningkatan dari tahun 2016 yang mencapai 244 orang (21,6\%), sedangkan pada tahun 2017 kasus anemia pada ibu hamil sebanyak 256 orang $(22.56 \%)$. Komplikasi persalinan akibat anemia dalam kehamilan diantaranya adalah perdarahan atonia uteri yaitu 4 kasus, partus lama 3 kasus.

Penelitian ini bertujuan untuk mencari hubungan antara faktor konsumsi tablet $\mathrm{Fe}$ dan faktor lama 
mengkonsumsi tablet $\mathrm{Fe}$ terhadap kejadian anemia dalam kehamilan.

\section{METODE PENELITIAN}

Metode penelitian yang digunakan adalah metode kuantitaif dengan pendekatan cross sectional. Populasi dalam penelitian ini adalah seluruh ibu hamil di wilayah puskesmas Cisayong periode Januari sampai dengan April 2018 berjumlah 454 orang. Tekhnik pengambilan sampel menggunakan proportional random sampling. Besaran sampel dihitung dengan menggunakan rumus sebagai berikut :

$$
\begin{aligned}
& n=\frac{z^{2}-\frac{a}{2} p(1-p) N}{d^{2}(N-1)+z^{2} 1-\frac{a}{2} p(1-p)} \\
& \mathrm{n}=\text { Besar sampel } \\
& Z_{(1-a / 2)}^{2}=\text { Nilai sebaran } \\
& \text { normal baku, } \\
& \text { besarnya } \\
& \text { tergantung } \\
& \text { tingkat } \\
& \text { kepercayaan } \\
& 1,96 \\
& \mathrm{P}=\text { Perkiraan } \\
& \text { proporsi pada } \\
& \text { populasi } \\
& \mathrm{N} \quad=\text { Jumlah } \\
& \text { Populasi } \\
& \mathrm{d}=\text { Tingkat } \\
& \text { kepercayaan } \\
& 0,05 \\
& =\frac{1.96 \cdot 0,22(1-0.22) 454}{0.05^{2}(454-1)+1.96 .0,22(1-0.22)} \\
& =\frac{1.96 \times 77.9}{0.0025(453)+0.336}
\end{aligned}
$$

Adapun penyebaran sampel dari tiap desa dapat dilihat pada tabel berikut:

\begin{tabular}{|c|c|c|c|c|}
\hline Desa & Populasi & Total Populasi & Ttl sampel & Sampel \\
\hline 1 & 38 & 454 & 104 & 9 \\
\hline 2 & 41 & 454 & 104 & 9 \\
\hline 3 & 37 & 454 & 104 & 8 \\
\hline 4 & 42 & 454 & 104 & 10 \\
\hline 5 & 36 & 454 & 104 & 8 \\
\hline 6 & 34 & 454 & 104 & 8 \\
\hline 7 & 38 & 454 & 104 & 9 \\
\hline 8 & 37 & 454 & 104 & 8 \\
\hline 9 & 41 & 454 & 104 & 9 \\
\hline 10 & 35 & 454 & 104 & 8 \\
\hline 11 & 37 & 454 & 104 & 8 \\
\hline 12 & 38 & 454 & 104 & 9 \\
\hline
\end{tabular}

Tekhnik pengambilan data adalah menggunakan data sekunder berdasarkan data penelitian Santi Srimulyati, Amd.Keb pada tahun 2018. Instrumen yang digunakan adalah format ceklist untuk mengetahui anemia pada ibu hamil, konsumsi tablet fe, dan lama mengkonsumsi tablet Fe. Analisis data menggunakan analisis bivariate dengan menggunakan Uji kai kuadrat dengan menggunakan formula: Sabri, dkk, 2006)

$$
\chi^{2}=\frac{\Sigma(\mathrm{O}-\mathrm{E})^{2}}{\mathrm{E}}
$$

Keterangan :

$$
\begin{aligned}
& \text { O : Frekuensi Observasi } \\
& \text { E : Frekuensi Ekspektasi } \\
& \text { (harapan) }
\end{aligned}
$$

\section{HASIL PENELITIAN}

1. Hubungan Konsumsi Tablet Fe Dengan Anemia Kehamilan 
Hubungan konsumsi tablet Fe dengan anemia dalam kehamilan di wilayah kerja Puskesmas Cisayong dapat dilihat pada tabel berikut :

Tabel 1.1 Hubungan konsumsi tablet Fe dengan anemia dalam kehamilan

\begin{tabular}{|c|c|c|c|c|c|c|c|}
\hline $\begin{array}{c}\text { Konsumsi } \\
\text { Fe }\end{array}$ & $\begin{array}{c}\text { Anemia } \\
(\mathrm{F})\end{array}$ & $\%$ & $\begin{array}{c}\text { Tidak } \\
\text { Anemia }(\mathrm{F})\end{array}$ & $\%$ & Total & $\%$ & $P$ \\
\cline { 1 - 5 } $\begin{array}{c}\text { Kadang- } \\
\text { Kadang }\end{array}$ & 19 & 65,5 & 10 & 34,5 & 29 & 100 & 0,00 \\
\hline Selalu & 5 & 6,7 & 70 & 93,3 & 75 & 100 & \\
\hline Total & 24 & 23,1 & 80 & 76,9 & 104 & 100 & \\
\hline
\end{tabular}

Hubungan antara konsumsi tablet $\mathrm{Fe}$ dengan anemia dalam kehamilan menunjukkan nilai $\mathrm{p}=0,00$. Jika menggunakan tingkat signifikansi $\alpha=0,05$ maka nilai $\mathrm{p}(0,031)<\alpha(0,05)$, sehingga disimpulkan bahwa hubungan antara konsumsi tablet $\mathrm{Fe}$ dengan anemia dalam kehamilan signifikan.

2. Hubungan lama konsumsi tablet $\mathrm{Fe}$ dengan Anemia Dalam kehamilan

Hubungan lama mengkonsumsi tablet $\mathrm{Fe}$ dengan aemia dalam kehamilan di wilayah kerja Puskesmas Cisayong dapat dilihat pada tabel berikut :

Tabel 1.2 Hubungan lama mengkonsumsi tablet Fe dengan anemia dalam kehamilan

\begin{tabular}{|c|c|c|c|c|c|c|c|c|}
\hline Hubungan & $\begin{array}{c}\text { Lama } \\
\text { Konsumsi } \\
\mathrm{Fe}\end{array}$ & $\begin{array}{l}\text { Anem } \\
\text { ia (F) }\end{array}$ & $\%$ & $\begin{array}{c}\text { Tidak } \\
\text { Anemia (F) }\end{array}$ & $\%$ & Total & $\%$ & $P$ \\
\hline lama & $\begin{array}{l}\text { Kurang dari } \\
3 \text { bulan }\end{array}$ & 12 & 25,5 & 35 & $\begin{array}{c}74, \\
5\end{array}$ & 47 & 100 & \multirow[t]{3}{*}{$\overline{0,62}$} \\
\hline mengkonsumsi & $\geq 3$ bulan & 12 & 21,4 & 44 & 78, & 56 & 100 & \\
\hline tablet & Total & 24 & 23,3 & 79 & 6,7 & 103 & 100 & \\
\hline
\end{tabular}

dengan anemia dalam kehamilan menunjukkan nilai $p=0,62$. Jika menggunakan tingkat signifikansi $\alpha=0,05$ maka nilai $\mathrm{p}(0,62)>\alpha(0,05)$, sehingga disimpulkan bahwa tidak terdapat hubungan antara lama mengkonsumsi tablet $\mathrm{Fe}$ dengan anemia dalam kehamilan.

\section{E. PEMBAHASAN}

1. Hubungan konsumsi tablet Fe Dengan Anemia Dalam Kehamilan

Hubungan antara konsumsi tablet $\mathrm{Fe}$ dengan anemia dalam kehamilan menunjukkan nilai $\mathrm{p}=0,03$ artinya terdapat hubungan antara konsumsi tablet $\mathrm{Fe}$ dengan anemia dalam kehamilan signifikan. Anemia Dalam kehamilan adalah kadar haemoglobin pada seorang wanita hamil kurang dari $10 \mathrm{gr} / \mathrm{dl}$ (Varney,2007). Anemia adalah turunnya kadar hemoglobin kurang dari 12,0 g/100 ml darah pada wanita yang tidak hamil dan kurang dari 10,0 $\mathrm{g} / 100 \mathrm{ml}$ darah pada wanita hamil. Anemia yang terkait dengan kehamilan adalah anemia defisiensi besi (hampir 95\%) Anemia Karena Kekurangan Zat Besi adalah suatu keadaan dimana jumlah sel darah merah atau hemoglobin (protein pengangkut oksigen) dalam sel darah berada dibawah normal, yang disebabkan karena kekurangan zat besi.

Zat besi adalah mineral yang dibutuhkan untuk membentuk sel darah merah. Selain itu mineral ini juga berfungsi sebagai komponen untuk membentuk mioglobin

(protein yang membawa oksigen ke otot). Salah satu unsur penting dalam proses pembentukan sel darah merah adalah zat besi. Zat besi dapat diperoleh dari makanan. Kekurangan zat besi dalam menu makanan seharihari dapat menimbulkan defisiensi zat besi (Nurhayati , dkk, 2014). Pada kehamilan kebutuhan oksigen lebih 
tinggi sehingga memicu peningkatan produksi eritropoetin. Akibatnya volume plasma bertambah dan sel darah merah meningkat. Namun peningkatan volume plasma terjadi dalam proporsi yang lebih besar jika dibandingkan peningkatan eritrosit sehingga terjadi penurunan konsentrasi hemoglobin akibat hemodilusi. Konsentrasi hemoglobin normal pada wanita hamil berbeda dengan wanita yang tidak hamil. Hal ini disebabkan karena pada kehamilan terjadi proses hemodilusi atau pengenceran darah, yaitu peningkatan volume plasma dalam proporsi yang lebih besar jika dibandingkan dengan peningkatan eritrosit. Hemodilusi berfungsi agar suplai darah untuk pembesaran uterus terpenuhi, melindungi ibu dan janin dari efek negative kehilangan darah saat proses melahirkan (Cunningham, 2007).

Hasil penelitian ini sejalan dengan hasil penelitian Nurhayati, dkk (2014) yang mendapatkan sebagian responden mengalami peningkatan nilai kadar $\mathrm{Hb}$ sesudah mengkonsumsi tablet fe. Sebelum mengkonsumsi tablet fe pada pengukuran I nilai $\mathrm{Hb}$ berada pada katagori rendah sebayak 17 orang ( 56\%). Sedangkan sesudah mengkosumsi fe pada pengukuran II nilai $\mathrm{Hb}$ berada pada katagori tinggi sebanyak 20 orang $(66,7 \%)$. Hal ini juga sejalan dengan penelitian Ariyani (2016) yang menemukan bahwa ada hubungan antara kepatuhan konsumsi tablet Fe dengan kejadian anemia $(\mathrm{p}=0,000)$. Dalampenelitinnya ariyani (2016) menjelaskan bahwa ibu hamil yang patuh mengkonsumsi tablet $\mathrm{Fe}$ memiliki resiko kejadian anemia lebih rendah dibandingkan ibu hamil yang tidak patuh dalam mengkonsumsi tablet $\mathrm{Fe}$, hal ini dikarenakan semakin baik kecukupan konsumsi tablet $\mathrm{Fe}$ maka tingkat kejadian anemia semakin rendah. Ibu hamil sangat memerlukan konsumsi tablet Fe, karena tablet $\mathrm{Fe}$ adalah tablet tambah darah untuk menanggulangi anemia gizi besi yang diberikan kepada ibu hamil. Di samping zat besi tidak hanya dibutuhkan oleh ibu saja tetapi juga untuk janin yang ada di dalam kandungannya (Manuaba, 2007).

2. Hubungan Lama Mengkonsumsi Tablet Fe Dengan Anemia Dalam Kehamilan

Hubungan antara lama mengkonsumsi tablet $\mathrm{Fe}$ dengan anemia dalam kehamilan menunjukkan nilai $\mathrm{p}=0,62$ sehingga disimpulkan bahwa tidak terdapat hubungan antara lama mengkonsumsi tablet $\mathrm{Fe}$ dengan anemia dalam kehamilan. Menurut Jordan (2004) zat besi merupakan mineral yang diperlukan oleh semua sistem biologi di dalam tubuh. Besi merupakan unsur esensial untuk sintesis hemoglobin, sintesis katekolamin, produksi panas dan sebagai komponen enzim-enzim tertentu yang diperlukan untuk produksi adenosin trifosfat yang terlibat dalam respirasi sel. Tablet tambah darah merupakan tablet yang diberikan kepada wanita usia subur dan ibu hamil. Bagi wanita usia subur diberikan sebanyak 1 (satu) kali seminggu dan 1 (satu) kali sehari selama haid dan untuk ibu hamil diberikan setiap hari selama masa kehamilannya atau minimal 90 (sembilan puluh) tablet. Setiap tablet tambah darah bagi wanita usia subur 
dan ibu hamil sekurangnya mengandung : a. Zat besi setara dengan $60 \mathrm{mg}$ besi elemental (dalam bentuk sediaan Ferro Sulfat, Ferro Fumarat atau Ferro Gluconat); dan b. Asam Folat 0,400 mg. (Menkes, 2014).

Hasil penelitian ini sejalan dengan penelitian Swamilaksita, P.D ( 2016) bahwa suplementasi multivitamin (MVM) dan multimikronutrien (MMN) memberikan hasil sangat efektif untuk membantu meningkatkan kualitas hasil kehamilan dibandingkan dengan suplementasi tunggal misalnya hanya $\mathrm{Fe}$ saja, maupun kombinasi 2-3 zat gizi misalnya kombinasi $\mathrm{Fe}$ dengan Asam folat atau kombinasi Fe dengan Vitamin C. Kebutuhan asupan makanan pada ibu hamil, khususnya energi dan mikronutrien akan meningkat selama kehamilan untuk mendukung perubahan dalam jaringan ibu dan pertumbuhan janin sehingga kurangnya asupan makanan akan menyebabkan gangguan kesehatan ibu dan pertumbuhan janin. Defisiensi mikronutrien yang cukup tinggi karena asupan dari sumber pangan tertentu akan sulit untuk memenuhi beberapa zat gizi yang dibutuhkan. Oleh karena itu, suplementasi zat gizi sangat diperlukan untuk menunjang kebutuhan tersebut selama kehamilan. Zat gizi yang perlu untuk disuplementasi adalah $\mathrm{Fe}$, vitamin B12, asam folat, dan DHA. suplementasi sebaiknya diberikan pada awal kehamilan atau bahkan sebelum kehamilan agar cadangan zat gizi dalam tubuh mampu memenuhi kebutuhan yang meningkat selama kehamilan. Dosis suplementasi yang digunakan harus sesuai dengan kebutuhan dan kondisi ibu hamil menurut asupan yang direkomendasikan berdasarkan peningkatan kebutuhan ibu hamil, yang disesuaikan pula dengan dosis anjuran dari WHO untuk suplementasi Fe, Folat, dan vitamin A serta anjuran WHO/UNICEF untuk suplementasi multimikronutrien. Suplementasi yang sebaiknya diberikan untuk meningkatkan hasil kehamilan atau mempertahankan zat gizi dalam tubuh selama kehamilan adalah suplementasi multigizi seperti multivitamin (MVM) dan multimikronutrien (MMN).

\section{F. SIMPULAN DAN SARAN}

Simpulan dalam penelitian ini adalah terdapat hubungan antara konsumsi tablet $\mathrm{Fe}$ dengan anemia dalam kehamilan dan tidak ada hubungan antara lama mengkonsumsi tablet $\mathrm{Fe}$ dengan anemia dalam kehamilan.

Saran untuk ibu hamil dianjurkan untuk mengkonsumsi tablet Fe selama kehamilan secara rutin dan teratur. Ibu hamil juga disarankan untuk mengkonsumsi multivitamin sehingga dapat meningatkan penyerapan $\mathrm{Fe}$ dalam mencegah anemia dalam kehmailan.

\section{G. DAFTAR PUSTAKA}

1. Ariyani, R, (2014), FaktorFaktor Yang Mempengaruhi Kejadian Anemia Pada Ibu Hamil Trimester III Di Wilayah Kerja Psukesmas Mojolaban Kabupaten Sukoharjo, Program Studi Ilmu Gizi, Fakultas ilmu Kesehatan Universitas Muhammadiyah Surakarta.

2. Cunningham, F.G, dkk. 2006. Obstetri Williams. Vol. 1. ed. 21. 
Jakarta: Penerbit Buku Kedokteran EGC

3. Jordan, Sue (2004), Farmakologi Kebidanan, EGC. Jakarta

4. Manuaba, 2012. Ilmu Kebidanan, Penyakit Kandungan dan KB, EGC, Jakarta

5. Nurhayati, Halimatusakdiah, Asniah,, (2014), Pengaruh Asupan Tablet Zat Besi Terhadap Kadar Haemoglobin (Hb) pada Ibu Hamil Di Puskesmas Kopelma Darussalam Tahun 2014, Idea Nursing Journal Vol. VI No. 3 ISSN: 2087 2879, diakses pada tanggal 19 Agustus 2019

6. Peraturan Menteri Kesehatan republic IndonesiaNomor 88 Taahun 2014 Tentang Standar Tablet Tambah darah bagi wanita usia subur dan ibu hamil http://sinforeg.litbang.depkes.go id/upload/regulasi/PMK_No._8 8 _ttg_Tablet_Tambah_Darah_p df, diakses pada tanggal 19 Agustus 2019

7. Rizky Ariyani (2016) http://eprints.ums.ac.id/42421/1/ NASKAH\%20PUBLIKASI.pdf

8. Saifuddin, $2010 . \quad$ Ilmu Kebidanan. Yayasan Bina Pustaka Sarwono Prawirohardjo, Jakarta

9. Sulistyoningsih, 2011. Gizi Kesehatan Ibu dan Anak. Graha Ilmu. Jogjakarta

10. Sabri.L., Hastono., 2006, Statistik Kesehatan, PT Raja Grafindo Persada, Jakarta

11. Sastroasmoro.S., Ismail.S., 1995, Dasar-Dasar Metodologi
Penelitian Klinis, Binarupa Aksara, Jakarta

12. Septianas,

http://digilib.unisayogya.ac.id/7 51/1/Septianas\%20Putri_20141 0104142_NASKAH\%20PUBLI KASI.pdf, 16 agustus 2019

13. Swamilaksita, P.D 2016), Efikasi Suplemeentasi Zat Gizi Pada Ibu Hamil Terhadap hasil Kehamilan, Universitas Esa Unggul, file:///D:/Downloads/768418879-1-SM\%20(1).pdf, 19 Agustus 2019

14. Varney.H., Kriebs.J., Gegor.C., (2007), Buku Ajar Asuhan Kebidanan (Varnoey's Midwifery) edisi 4 volume I, EGC, Jakarta 